\title{
Mercury toxicity potential from artisanal and small scale gold mines in Lebong Regency, Bengkulu Province
}

\author{
Ali Munawar ${ }^{1 *}$, Hery Suhartoyo ${ }^{2}$, and Putri Suci Asriani ${ }^{3}$ \\ ${ }^{1}$ Soil Science Department, Faculty of Agriculture, University of Bengkulu, Indonesia \\ ${ }^{2}$ Forestry Department, Faculty of Agriculture, University of Bengkulu, Indonesia \\ ${ }^{3}$ Agricultural Economics Department, Faculty of Agriculture, University of Bengkulu, Indonesia
}

\begin{abstract}
Artisanal and small scale gold mining (ASGM) is considered as the largest source of mercury pollution worldwide. The ASGM has been practiced for years in the area of Lebong Regency of Bengkulu Province. To extract gold from the ores, miners use a simple technique called Gelondong. This practice involves amalgamation process which forms amalgam, a mixure composed of mercury and gold. These amalgamation generates liquid and solid wastes (tailings) which still contain significant amount of mercury. Consequently, ASGM activities can potentially create mercury contamination of the environment, especially aquatic ecosystems. This study was aimed to investigate the concentration and distribution of total mercury in rivers to which wastes from ASGM communities in three villages of North Lebong District were dumped. Water and streambed sediments along the rivers were collected and brought to the laboratory for total mercury analysis. Data showed that total mercury was not detected in the river water but high in the river sediments with high variations among lactions from 0.11 to $110.37 \mathrm{mg}$ $\mathrm{kg}^{-1}$. Apparently, total mercury tended to decrease with the distance from it source. High amounts of mercury in the river sediments could potentially spread to wider area and cause bioaccumulation in aquatic organisms, especially fish which can be dangerous to consume.
\end{abstract}

Keywords: small gold mines; mercury; contamination; river, sediments.

\section{Introduction}

Artisanal and small scale gold mining (ASGM) is one important causes of deforestation and the considered as the largest source of mercury pollution on Earth [1]. In many areas in developing countries ASGM activities cause destruction of forest through reoval of soil and vegetation, leaving wastes on the sites [2]. In most ASGM practices, miners use mercury to extract gold from ores through amalgamation process in which gold is separated from the ores and form amalgam, a mixture of mercury and gold. This amalgam is then heated to evaporate the mercury, leaving gold particles [1, 3].

Lebong Regency is one of important areas of ASGM in Bengkulu, Indonesia. Like in other parts of the country, most ASGM use Gelondong techique. This practice involve several stages: ore size reduction (crushing and milling), concentrating with water, amalgamation with mercury, and gold recovery through evaporation of the mercury from mercury-gold amalgam $[2,4]$. Because water is used in this technique, the miners usually build the equipment in their yards or near a river. This practice produces liquid as well as solid wastes (tailings), while the recovery stage releases mercury to the atmosphere [1-4]. Miners discard liquid wastes and the tailings that still contain significant

\footnotetext{
* Corresponding author: a.munawar008@gmail.com
}

amounts of mercury residues to public streams or rivers whitout any treatment. Therefore, mercury may be transported and accumulated in the streambed sediments and can contaminate aquatic ecosystem where it may then bioaccumulate in fish muscles which can be dangerous to consume and agricultural lands where it can be absorbed by growing crops $[1,6,7]$.

Based on the above mentioned processes, it is obvious that ASGM practices can create mercury toxicity effects to the environment and human health are very obvious. This initial study was aimed to investigate the concentration and distribution of mercury in rivers to which wastes were dumped from ASGMs in the North Lebong District.

\section{Materials and Methods}

\subsection{Study Site Condition}

This study was conducted in North Lebong District, especially in the area of three villages: Lebong Tambang, Sukasari, and Kampung Jawa, where most of the population are traditional gold miners (ASGM). The mining activities in the area have been taking places for 
years in an old hard rock vein mountain left by the Dutch colonial. The miners take gold ores from the mountain and process them in their yards. To extract the gold, they use the Grinding Mills (Gelondong) technique which involves amalgamation using mercury. This process produces liquid wastes and solid wastes (tailings). These wastes are initially dumped to a small pond before being discharged to a river so-called Air Racun which passes through Lebong Tambang, Lokasari, and Kampung Jawa villages and eventually flows to a relatively bigger river called Air Kotok.

\subsection{Water and Sediment Sampling}

Composite water and streambed sediments were collected from six locations: (1) Location 1, in the upper stream of Air Racun river, about 50-m up from gold ore processing in Lebong Tambang village; (2) Location 2, about $200 \mathrm{~m}$-down stream of Air Racun river from Location 1 in Lebong Tambang village; (3) Location 3, about 600 m-down stream of Air Racun river from Location 2 in Kampung Jawa village, (4) Location 4, the down stream of the Air Racun river, about 800 m-down from Location 3 in Kampung Jawa village; (5) Location 5, about 20-m up from the tributary of the Air Racun river and Air Kotok river in Kampung Jawa village; and (6) Location 6, in the Air Kotok river about 500 m-down stream from the tributary of Air Racun river and Air Kotok river. The water samples were collected using a plastic cup at least three replicate grabs at $0-15 \mathrm{~cm}$ depth, placed in plastic bottles, and kept in a cooling box. The collected water samples were then acidified with concentrated nitric acid and filtered through a Whatman 45 filter paper, and brought to the Integrated Research and Testing Institute Laboratory, Gadjah Mada University, Yogyakarta for total mercury $(\mathrm{Hg})$ analysis using Mercury Analyzer method.

The composite sediment samples were taken at least three replicate grabs from the streambed of the rivers using plastic shovels, placed into plastic bags, kept in a cooling box, and brought to the Soil Science Laboratory, University of Bengkulu for further sample preparation. The collected sediment samples were airdried, sieved through a 2-mm diameter sieve, and brought to the Integrated Research and Testing Institute Laboratory, Gadjah Mada University, Yogyakarta for total $\mathrm{Hg}$ analysis using Mercury Analyzer.

\section{Results and Discussions}

Total mercury $(\mathrm{Hg})$ concentrations in the water and river sediments are outlined in Table 1 . Mercury $(\mathrm{Hg})$ was not detected in water at all sampling locations, but found high in river sediments, including in the most upperstream of the Air Racun river, a point before water body flows passing the gold ore processing area. The presence of a relatively high total $\mathrm{Hg}$ concentration $\left(5.12 \mathrm{mg} \mathrm{kg}^{-1}\right)$ in the upperstream might be due to the additions of $\mathrm{Hg}$ from the evaporated $\mathrm{Hg}$ to the atmosphere during its recovery process.

Table 1. Total mercury $(\mathrm{Hg})$ concentration in water and sediment at different locations.

\begin{tabular}{|l|c|c|}
\hline \multirow{2}{*}{ Locations } & \multicolumn{2}{|c|}{$\begin{array}{c}\text { Total Hg Concentration } \\
\left(\mathrm{mg} \mathrm{kg}^{-1}\right)\end{array}$} \\
\cline { 2 - 3 } & Water & Sediment \\
\hline Location 1 & ND & 5.12 \\
\hline Location 2 & ND & 110.37 \\
\hline Location 3 & ND & 94.01 \\
\hline Location 4 & ND & 21.00 \\
\hline Location 5 & ND & 0.11 \\
\hline Location 6 & ND & 86.66 \\
\hline
\end{tabular}

$\mathrm{ND}=$ Not Detected

Table 1 indicates that total $\mathrm{Hg}$ concentrations in river sediments were very high but varied along the river flow (locations) which passed across the gold ore processing area (Location 2 to Location 4). Apparently total $\mathrm{Hg}$ concentrations in the sediments of Air Racun river decreased along the stream flow, from $110.37 \mathrm{mg}$ $\mathrm{kg}^{-1}$ in Location 2 to $21.00 \mathrm{mg} \mathrm{kg}^{-1}$ in Location 4 or at the end of the Air Racun river stream. This may explain that the total $\mathrm{Hg}$ deposition in the streambed is dependent on the distance from the source. The closer the locations from the source, the higher the total $\mathrm{Hg}$ was deposited. Because $\mathrm{Hg}$ element is a noble metal with low solubility in water, most $\mathrm{Hg}$ tended to settle in the streambed of the river. This deposited $\mathrm{Hg}$ could then be transformed by anarobic organisms into to methylmercury (MeHg). This compound is known to be readily absorbed and retained by any organisms such as phytoplankton, ingested by zooplanton and fish, thereby contaminating the food chain [1,3]. Therefore, it is obviously dangerous to consume fish that live in rivers or other aquatic ecosystems. Studies in 19 developing countries in South America, Asia, and Africa found residents of nearby \& downstream communities of ASGM areas that consumed fish heavily contaminated with methylmercury experienced neurologic effects, kidney effects, and immunotoxic effects [3].

Table 1 also explains that although its concentration in the downstream of the Air Racun river was relatively lower compared to the upperstream, discharged $\mathrm{Hg}$ from the Air Racun river stream seemed to have increased $\mathrm{Hg}$ accumulation in the Air Kotok river. Total $\mathrm{Hg}$ concentration in the sediments of Air Kotok river located 500-m down from the tributary of the Air Racun river (Location 6) was much higher (86.66 $\mathrm{mg} \mathrm{kg}^{-1}$ ) than that of the upperstream before the tributary (Location 5) $\left(0.11 \mathrm{mg} \mathrm{kg}^{-1}\right)$. High $\mathrm{Hg}$ concentration in the streambed sediments of Air Kotok river could potentially contaminate downstream community of the river. This potential contamination could be possibly spread to the bigger river to which Air Kotok flows, the Ketahun river. 


\section{Conlusions}

This study indicates that the total $\mathrm{Hg}$ released from gold extraction using amalgamation as practiced in most ASGMs in the North Lebong District had potential threat to the environment, especially aquatic ecosystem such as river. Although not detected in the river water, high total $\mathrm{Hg}$ concentrations in the sediments of the Air Racun and Air Kotok rivers could potentially be toxic to and absorbed by aquatic organisms especially fish, and over time accumulate in their muscles and be dangerous to consume. Potential spread of mercury contamination to the wider environment could occur as identified by its higher concentration in the streambed sediments of Air Kotok.

Serious attention must be paid to the development of ASGM in the area. This is not only to protect mk spreading potential threats of the mercury but also to reduce further environmental destruction such as deforestation of the area. This is important especially to enhance the low-carbon development movement in Indonesia.

The authors thank the Directorate of Research and Community Service, the Ministry of Research, Technology, and Higher Education of the Republic of Indonesia which has funded the study through the Applied Research of Higher Education Institution's Excellence 2018.

\section{References}

1. L. J. Esdaile and J. M. Chalker. Chem. Eur. J. 24 (2018)

2. S. A. Abdul-Wahab and F.A. Marikar. Centr. Eu. J. Engin. 2(2) (2012)

3. H. Gibb and K.G. O'leary. Env. Health Perspectives. Nat. Inst. Env. Health Sci. 122 (7) (2014)

4. M. Rajaee, M. Obiri, A. Green, R. Long, S. M. Cobbina, V. Nartey, D. Buck, E. Antwi, N. Basu. Int. J. Environ. Res. Public Health. 12 (2015)

5. C. Aspinall. Small Scale Mining in Indonesia. 79 Mining, Mineral, and Sustainable Development, (2001)

6. F.K.F Macdonald, M. Lund, M. Blanchette, C. McCullough. An Interdiciplinary Response to Mine Water Challanges- Sui, Sun \& Wang (EDS), 401 (2014)

7. K. Kannan, R.G. Smith Jr., R.F. Lee, H.L. Windon, P.T. Heimuller, J.M. MaCulay, J.K. Summers. Arch. Env. Contam. Tox. 34, 109 (1998) 